\title{
FAKTOR PENERIMAAN PENDAPATAN ASLI DAERAH DAN DANA \\ PERIMBANGAN TERHADAP BELANJA DAERAH DI KABUPATEN TANAH LAUT
}

\author{
Eni Suasri ${ }^{1}$, Noor Amelia ${ }^{2}$ \\ 1), 2) Politeknik Negeri Tanah Laut \\ Jl. A. Yani Km. 6 Ds. Panggung Kec. Pelaihari Kab. Tanah Laut, Kalimantan Selatan \\ E-mail: ${ }^{1}$ enisuasri@gmail.com ${ }^{2}$ noor.amelia2012@gmail.com
}

\begin{abstract}
Abstrak
Belanja Daerah dibagi dalam dua kelompok yaitu belanja rutin dan pembangunan. Berdasarkan data anggaran Pendapatan dan Belanja Daerah Kabupaten Tanah Laut masih tergantung pada Dana Perimbangan. Penelitian ini bertujuan untuk mengetahui besarnya pengaruh Pendapatan Asli Daerah (PAD) terhadap Belanja Daerah dan besarnya pengaruh Dana Perimbangan terhadap Belanja daerah di Kabupaten Tanah laut menentukan kebijakan yang tepat untuk anggaran belanja daerah di Kabupaten tanah Laut. Metodologi penelitian yang digunakan adalah pengambilan sampel dengan teknik sensus, metode pengumpulan data dengan menggunakan teknik wawancara dan studi pustaka. Teknik analisis data menggunakan statistik regresi berganda dengan menggunakan aplikasi SPSS 16.0 for Windows. Serta uji asumsi klasik.

Dari penelitian yang telah di laksanakan diperoleh data dengan asumsi dari uji anova atau F-test, didapat F-hitung adalah 4,908 dengan tingkat signifikan $=0,00$ jauh lebih kecil dari derajat kepercayaan $95 \%(\mathrm{a}=5 \%)$ maka model regresi bisa dipakai untuk memprediksi belanja daerah. Dengan kata lain PAD dan dana Perimbangan berpengaruh terhadap belanja daerah. Nilai t-statistik keduanya masing-masing adalah 0,372 dan 44,187. Dengan demikian dapat dinyatakan bahwa pengaruh signifikasi Pendapatan Asli Daerah (PAD) terhadap pengeluaran atau Belanja Daerah (BD) lebih lemah daripada pengaruh Dana Perimbangan (DP) terhadap pengeluaran atau Belanja Daerah (BD).
\end{abstract}

Kata kunci: Belanja daerah, Dana perimbangan, Pendapatan asli daerah

\section{PENDAHULUAN}

Belanja daerah atau pengeluaran daerah (lokal expenditures) adalah pengeluaran yang dilakukan oleh Pemda untuk melaksanakan wewenang dan tanggung kepada masyarakat dan pemerintah diatasnya (pemerintah propinsi dan pemerintah pusat). Pada prakteknya belanja dibagi dalam dua kelompok: belanja rutin dan pembangunan. Belanja rutin adalah belanja keluarannya tidak berupa fisik, dan terjadi berulang-ulang sepanjang waktu atau periode, misalnya gaji pegawai, belanja barang/alat-alat tulis kantor, dan belanja perjalanan dinas. Belanja pembangunan adalah yang menghasilkan wujud fisik, seperti gedung, jalan, jembatan, irigasi dan sebagainya, yang masa manfaatnya lebih dari satu tahun. Belanja pembangunan ini pada akhirnya akan melahirkan kapital publik.

Dalam kenyataan belanja rutin dan pembangunan selalu mengalami peningkatan setiap tahunnya, persentase belanja rutin/tidak langsung terhadap total belanja daerah cukup tinggi bila dibandingkan dengan bagian belanja pembangunan, hal ini diakibatkan oleh pos belanja pegawai yang rata-rata pertahunnya mencapai lebih dari 50\% dari total belanja rutin/tidak langsung.

Berdasarkan teori Keynes APBD/N merupakan salah satu mesin pendorong perkembangan ekonomi. Peranan APBD sebagai pendorong salah satu penentu tercapainya target dan sasaran makro 
ekonomi daerah diarahkan untuk mengatasi berbagai kendala dan permasalahan pokok yang merupakan tantangan dalam mewujudkan agenda masyarakat yang sejahtera dan mandiri.

Pendapatan Asli Daerah (PAD) Kabupaten Tanah Laut mengalami peningkatan setiap tahunnya. Berdasarkan data anggaran Pendapatan dan Belanja Daerah Kabupaten Tanah Laut masih tergantung pada dana perimbangan. Dominasi dana perimbangan terhadap sumbangan total penerimaan daerah menunjukkan bahwa Kabupaten Tanah Laut masih tergantung dengan bantuan dari pemerintah pusat.

Dengan demikian untuk menentukan kebijakan yang tepat untuk anggaran belanja daerah di Kabupaten tanah Laut, pemerintah perlu mengetahui besarnya pengaruh Pendapatan Asli Daerah (PAD) terhadap Belanja Daerah dan besarnya pengaruh Dana Perimbangan terhadap Belanja daerah di Kabupaten Tanah laut.

\section{METODOLOGI PENELITIAN}

Rancangan penelitian yang digunakan adalah pengambilan sampel dengan teknik sensus. Data umum digunakan untuk memberikan gambaran tentang wilayah penelitian yang meliputi keadaan geografis dan administratif, kebijakan pembangunan daerah dan kondisi keuangan daerah. Sedangkan data khusus dimaksud untuk dianalisa, yang menjadi masalah penelitian yaitu:

1. Data realisasi Anggaran Pendapatan dan Belanja Daerah (RAPBD) Kabupaten Tanah Laut Tahun 20032012.

2. Data Pendapatan Asli Daerah (PAD) Kabupaten Tanah Laut Tahun 19732012.
3. Data dana perimbangan Kabupaten Tanah Laut tahun 2003-2012.

4. Data belanja daerah Kabupaten Tanah Laut tahun 2003-2012.

5. Data-data lain yang terkait dan berhubungan dengan penelitian ini.

Penelitian ini menggunakan data sekunder, yaitu data yang diperlukan untuk penelitian ini terdiri atas data Realisasi Anggaran Pendapatan dan belanja daerah (RAPBD) Kabupaten Tanah Laut Tahun 2003-2012. Menurut Undang-Undang No. 22 Tahun 2010, PAD adalah Penerimaan yang diperoleh dari sumber-sumber dalam wilayahnya sendiri yang dipungut berdasarkan peraturan Daerah sesuai dengan peraturan perundang-undangan yang berlaku.

Metode pengumpulan data dengan menggunakan teknik wawancara dan studi pustaka. Wawancara yaitu tanya jawab Langsung dengan responden yang dilakukan untuk melengkapi kekurangan data yang ada. Studi pustaka, yaitu metode pengumpulan data dengan menggunakan buku dan literatur lain yang berhubungan dengan penelitian ini.

Metode Analisis Data menggunakan statistik regresi berganda karena analisis regresi dapat digunakan untuk melihat pengaruh antar variabel bebas terhadap variabel terikat (Sulaiman, 2004: 1) tapi sebelumnya akan dilakukan uji asumsi klasik (best linear unbiased estimator-blue). Kemudian untuk pengambilan kebijakan dilakukan dengan metode AHP (analytic hierarchy process) dimana proses ini untuk mengukur pembobotan dalam mengambil suatu keputusan kebijakan yang akan di lakukan oleh daerah dimana metode ini di kembangkan oleh Thomas L Saaty pada tahun 1980. Penelitian ini menggunakan aplikasi SPSS 16.0 for Windows. 
HASIL DAN PEMBAHASAN

\section{Gambaran Umum}

Kabupaten tanah Laut melalui kebijakan penataan ruang wilayahnya telah memprioritaskan 5 (lima) kawasan dengan masing-masing fungsi strategisnya yaitu:

1. Kawasan industri dipusatkan di kecamatan Bati-Bati dan Jorong.

2. Pertanian di kecamatan Kurau.

3. Perikanan laut di kecamatan Kurau, Takisung, Panyipatan, Jorong dan Kintap.

4. Pertambangan di kecamatan Jorong dan Kintap.

5. Wisata di Kecamatan Takisung, Panyipatan, Jorong dan Pelaihari.

\section{Hasil Analisis Data}

\section{Pendapatan Asli Daerah (PAD)}

Besar kecilnya pendapatan asli daerah (PAD) mencerminkan kemandirian suatu wilayah dalam membiayai pelaksanaan pembangunan di daerahnya.Semakin besar PAD suatu daerah berarti semakin mandiri daerah tersebut melaksanakan pelaksanaan daerah.

Jumlah realisasi PAD Kabupaten Tanah Laut tahun 2003-2012 dapat dilihat pada Tabel 1 Realisasi PAD Kabupaten Tanah Laut dibawah ini:

Tabel 1

Realisasi Pad Kabupaten Tanah Laut 2003-2012

\begin{tabular}{|c|c|c|c|}
\hline Tahun & PAD (Rp) & BD (Rp) & $\frac{P A D}{B D} \times 100$ \\
\hline 2003 & 11.701 .318 .321 & 121.192 .000 .562 & 9,66 \\
\hline 2004 & 13.738 .409 .442 & 139.239 .000 .056 & 9,87 \\
\hline 2005 & 13.566 .755 .989 & 199.658 .005 .555 & 6,79 \\
\hline 2006 & 13.939 .391 .887 & 223.525 .328 .942 & 6,24 \\
\hline 2007 & 15.172 .142 .445 & 162.435 .000 .000 & 9,34 \\
\hline 2008 & 15.277 .851 .112 & 100.638 .000 .000 & 15,18 \\
\hline 2009 & 15.523 .328 .666 & 229.007 .923 .785 & 6,78 \\
\hline 2010 & 16.315 .799 .000 & 265.161 .009 .362 & 6,15 \\
\hline 2011 & 16.947 .917 .023 & 135.678 .001 .240 & 12,49 \\
\hline 2012 & 18.609 .723 .001 & 288.212 .000 .469 & 6,46 \\
\hline
\end{tabular}

Berdasarkan Tabel 1 di atas, PAD Kabupaten Tanah Laut dari tahun 2003 sampai tahun 2012 selalu mengalami peningkatan yang cukup berarti. PAD Kabupaten Tanah Laut tahun 2003 sebesar Rp 11,701 miliar dan terus mengalami peningkatan sampai tahun 2005 mengalami penurunan sebesar Rp 13,566 miliar. Setelah tahun 2006 PAD Kabupaten Tanah Laut mengalami peningkatan. PAD paling besar diperoleh pada tahun 2003 dengan Rp. 11.701 miliar. Penerimaan PAD selama ini sangat dominan oleh pajak Kendaraan Bermotor (PKB) dan Bea Balik Nama Kendaraan Bermotor (BBNKB). Secara teoritis, pendapatan daerah akan sangat dipengaruhi oleh kondisi perekonomian suatu daerah atau dengan kata lain bahwa perkembangan ekonomi harus berkorelasi positif dengan pendapatan daerah. Rata-rata PAD Kabupaten Tanah Laut Pada Tahun 2003-2012 adalah sebesar Rp. 17,917 miliar.

Realisasi APBD mengalami fluktuasi, pada tahun 2004 realisasi sebesar 9,86\% dan menurun pada tahun 2006 sebesar 6,23\% kemudian meningkat lagi pada tahun 2007 sebesar $8,72 \%$ tapi menurun ditahun 2008 sebesar 1,51\% namun setelah tahun 2008 realisasi mengalami peningkatan kembali di tahun 2009 sebesar $6,77 \%$ tapi menurun lagi tahun 2011 sebesar $1,25 \%$.

\section{Dana Perimbangan}

Dana perimbangan memberikan penjelasan bahwa pemanfaatan sumber daya nasional di arahkan untuk mendukung pembiayaan yang dialokasikan kepada daerah sesuai dengan potensi dan hasil daerah guna melaksanakan otonomi daerah.Pengalokasian sumber daya nasional juga dimaksudkan untuk mengurangi kesenjangan antara daerah bersangkutan. Potensi fiscal daerah sebagai sumber 
pembiayaan dikelola oleh daerah untuk membiayai kebutuhannya dalam melayani masyarakat. Realisasi Dana Perimbangan Kabupaten Tanah Laut dari tahun 20032012 dapat dilihat pada tabel 2 dana perimbangan Kabupaten Tanah Laut

\section{Tabel 2}

Realisasi Dana Perimbangan Kabupaten Tanah Laut 2003-2012

\begin{tabular}{|r|c|c|c|}
\hline Tahun & PDP $(\mathrm{Rp})$ & PBD $(\mathrm{Rp})$ & $\frac{P A D}{B D} \times 100$ \\
\hline 2003 & 119.490 .230 .000 & 121.192 .000 .562 & 98,60 \\
\hline 2004 & 126.260 .490 .000 & 139.239 .000 .056 & 90,68 \\
\hline 2005 & 197.091 .110 .030 & 199.658 .005 .555 & 98,71 \\
\hline 2006 & 219.585 .600 .875 & 223.525 .328 .942 & 98,24 \\
\hline 2007 & 161.263 .096 .324 & 162.435 .000 .000 & 99,28 \\
\hline 2008 & 100.360 .000 .214 & 100.638 .000 .000 & 99,72 \\
\hline 2009 & 225.483 .217 .000 & 229.007 .923 .785 & 98,46 \\
\hline 2010 & 262.845 .000 .000 & 265.161 .009 .362 & 99,13 \\
\hline 2011 & 127.730 .000 .000 & 135.678 .001 .240 & 94,14 \\
\hline 2012 & 286.602 .590 .070 & 288.212 .000 .469 & 99,44 \\
\hline
\end{tabular}

Berdasarkan tabel 2 di atas dana perimbangan Kabupaten Tanah Laut mengalami fluktuasi yang tidak terlalu tajam dimana dari tahun 2003-2006 mengalami peningkatan yaitu $\mathrm{Rp} 119,490$ miliar, Rp 126,260 Miliar, Rp 197,091 miliar, Rp 219,585 miliar, tetapi menurun pada tahun 2008 sebesar Rp 100,360 miliar.

Dana perimbangan Kabupaten Tanah laut paling besar diperoleh pada tahun 2012 Rp 290,904 miliar sedangkan paling kecil diperoleh pada tahun 2008 dengan Rp 100,360 miliar. Dan rata-rata dana perimbangan Kabupaten Tanah Laut pada tahun 2003-2012 adalah sebesar Rp 204.647 miliar.

Realisasi APBD tertinggi pada tahun 2008 sebesar $99,72 \%$ dan terendah pada tahun 2006 yaitu 77,52\%, dimana pada akhir tahun 2005 terjadi pemekaran kabupaten baru di propinsi Kalimantan selatan, yang mempengaruhi jumlah DAU yang diterima Kabupaten Tanah laut. Adapun peningkatan setelah tahun 2005 disebabkan karena adanya peningkatan porsi DAU terhadap penerimaan dalam negeri dan peningkatan gaji PNS.

\section{Belanja Daerah}

Belanja daerah adalah belanja dalam APBD yang diarahkan untuk mendukung penyelenggaraan pemerintahan, pembangunan dan pembinaan pembangunan kemasyarakata. Secara umum belanja daerah dapat dikategorikan ke dalam belanja aparatur dan belanja public.Seiring perubahan peraturan perundang-undangan di bidang administrasi pengelolaan keuangan daerah sejak pemberlakuan Kemendagri Nomor 13 tahun 2009 yang disajikan dalam neraca daerah.

Prioritas belanja daerah yang telah dicanangkan oleh pemerintah kabupaten Tanah laut, lebih diarahkan pada penanggulangan kemiskinan dan kesenjangan social, revitalisasi pertanian dan pedesaan yang masuk dalam anggaran belanja rutin daerah.Sedangkan investasi dan ekspor serta peningkatan infrastruktur masuk dalam anggaran belanja pembangunan daerah.

Tabel 3

Rincian Data Belana Daerah Kabupaten Tanah Laut 2003-2012 (dalam Rupiah)

\begin{tabular}{|r|c|r|c|}
\hline Tahun & Belanja & Belanja Rutin & Total BD \\
\hline 2003 & 12.249 .829 .916 & 108.942 .170 .600 & 121.192 .000 .562 \\
\hline 2004 & 15.879 .382 .224 & 125.359 .617 .800 & 139.239 .000 .056 \\
\hline 2005 & 75.237 .500 .000 & 125.420 .505 .500 & 199.658 .005 .555 \\
\hline 2006 & 63.491 .565 .560 & 160.033 .763 .300 & 223.525 .328 .942 \\
\hline 2007 & 43.733 .121 .000 & 118.701 .879 .000 & 162.435 .000 .000 \\
\hline 2008 & 47.213 .870 .000 & 53.425 .130 .000 & 100.638 .000 .000 \\
\hline 2009 & 25.478 .050 .360 & 203.529 .873 .300 & 229.007 .923 .785 \\
\hline 2010 & $13.379 .078 . .000$ & 251.781 .931 .300 & 265.161 .009 .362 \\
\hline 2011 & 23.277 .531 .120 & 111.400 .470 .100 & 135.678 .001 .240 \\
\hline 2012 & 55.755 .474 .000 & 232.456 .526 .400 & 288.212 .000 .469 \\
\hline
\end{tabular}

Berdasarkan Tabel 3 di atas, tahun 2003 total belanja daerah Kabupaten Tanah Laut sebesar 121,192 miliar dan mengalami peningkatan sampai tahun 2006, tetapi pada tahun 2007 sampai tahun 2008 mengalami penurunan. Tahun 2009 mengalami peningkatan sebesar 229,007 miliar. Dan 
setiap tahun ketahun berikutnya terjadi ketidakstabilan belanja daerah total belanja daerah Kabupaten Tanah Laut paling besar pada tahun pada tahun 2012 sebesar Rp 307,145 miliar dimana belanja rutin yaitu belanja aparatur (diluar gaji PNS), terutama untuk menampung belanja barang dan jasa, perjalanan dinas dan belanja pemeliharaan. Kenaikan ini juga didasarkan pada asumsi terkait dengan kondisi perekonomian seperti kenaikan bahan bakar minyak,kapasitas kebutuhan fiscal daerah, tingkat inflasi dan suku bunga. Selain itu kenaikan belanja gaji berhubungan dengan penerimaan pegawai negeri sipil dalam beberapa tahun ke depan yang merupakan salah satu variable dasar penyusunan DAU. Belanja daerah yang paling rendah pada tahun 2008 dengan Rp 100,638 miliar, ratarata belanja daerah Kabupaten Tanah laut pada tahun 2003-2012 adalah sebesar Rp 214,219 miliar.

\section{Analisis Hasil Penelitian}

\section{Uji Validitas dan Reliabilitas}

a. Uji Validitas

Uji Validitas Item atau butir dapat dilakukan dengan menggunakan software SPSS. Untuk proses ini, akan digunakan Uji Korelasi Pearson Product Moment. Dalam uji ini, setiap item akan diuji relasinya dengan skor total variabel yang dimaksud. Dalam hal ini masingmasing item yang ada di dalam variabel $\mathrm{X}$ dan $\mathrm{Y}$ akan diuji relasinya dengan skor total variabel tersebut.

Tabel 4

Correlations

\begin{tabular}{|ll|r|r|r|}
\hline & & PAD & DP & $\begin{array}{r}\text { Belanja } \\
\text { Daerah }\end{array}$ \\
\hline Pendapatan Asli Daerah & Pearson Correlation & 1 & $.893^{* *}$ & $.893^{* *}$ \\
& Sig. (2-tailed) & & .000 & .000 \\
& $\mathrm{~N}$ & 40 & 40 & 40 \\
\hline Dana Perimbangan & Pearson Correlation & $.893^{* *}$ & 1 & $.998^{* *}$ \\
& Sig. (2-tailed) & .000 & & .000 \\
& $\mathrm{~N}$ & 40 & 40 & 40 \\
\hline Belanja Daerah & Pearson Correlation & $.893^{* *}$ & $.998^{* *}$ & 1 \\
& Sig. (2-tailed) & .000 & .000 & \\
& $\mathrm{~N}$ & 40 & 40 & 40 \\
\hline
\end{tabular}

Dari tabel 4 Correlations di peroleh data Pendapatan Asli Daerah dengan Belanja Daerah diperoleh nilai r-hitung 0,893 yang lebih besar dari nilai r-tabel 0,403 dengan signifikan 0,01 ini menyatakan bahwa data tersebut valid. Dana Perimbangan dengan Belanja Daerah diperoleh nilai r-hitung 0,998 yang lebih besar dari nilai r-tabel 0,403 dengan signifikan 0,01 ini menyatakan bahwa data tersebut valid. Ini menunjukkan bahwa data yang diperoleh layak untuk dilakukan pengujian statistik selanjutnya.

\section{b. Uji Reliabilitas}

Dalam statistik SPSS Uji Reliabilitas berfungsi untuk mengetahui tingkat kekonsistensian alat penggali data yang digunakan oleh peneliti sehiggaalat penggali data tersebut dapat dihandalkan, walaupun penelitian dilakukan berulangkali dengan alat penggali data yang sama.

Tabel 5

Reliabilitas Statistik

\begin{tabular}{|r|r|}
\hline Cronbach's Alpha & N of Items \\
\hline .777 & \\
\hline
\end{tabular}

Berdasarkan tabel 5 Reliabilitas statistik diperoleh alpha 0,777, sedangkan nilai alpha pada r-tabel 0,403 Ini menunjukkan bahwa alpha hitung Lebih dari dari r-tabel, sehingga dapat disimpulkan bahwa alat pengumpul data yang digunakan reliabel atau terpercaya.

\section{Uji Asumsi Klasik}

Salah satu syarat untuk bisa menggunakan persamaan model regresi adalah terpenuhinya asumsi klasik. Untuk nilai pemeriksa yang tidak bisa dan efisien (best Linear Unbiased Estimator - Blue) dari suatu persamaan regresi dengan metode least square perlu dilakukan pengujian untuk mendapatkan model regresi yang dihasilkan memenuhi persyaratan asumsi 
klasik. Hasilnya tidak terjadi Multikolieritas, asumsi non autokorelasi terpenuhi, tidak terjadi heteroskedastisitas pada model regresi, dan asumsi kenormalan terpenuhi.

\section{Uji Regresi Linear Berganda}

Tabel 6

Hasil Run Spss Untuk Descriptive Uji Regresi Linear Berganda

\begin{tabular}{|c|c|c|c|c|}
\hline & & $\begin{array}{l}\text { Belanja } \\
\text { Daerah }\end{array}$ & PAD & Dana Perimbangan \\
\hline \multirow[t]{3}{*}{ Pearson Correlation } & Belanja Daerah & 1.000 & .893 & .998 \\
\hline & PAD & .893 & 1.000 & .893 \\
\hline & Dana Perimbangan & .998 & .893 & 1.000 \\
\hline \multirow[t]{3}{*}{ Sig. (1-tailed) } & Belanja Daerah & & .000 & .000 \\
\hline & PAD & .000 & & .000 \\
\hline & Dana Perimbangan & .000 & .000 & \\
\hline \multirow[t]{3}{*}{$\mathrm{N}$} & Belanja Daerah & 40 & 40 & 40 \\
\hline & $\mathrm{PAD}$ & 40 & 40 & 40 \\
\hline & Dana Perimbangan & 40 & 40 & 40 \\
\hline
\end{tabular}

Dari tabel 6 diperoleh korelasi antara variabel Pendapatan Asli Daerahdengan Belanja Daerah diperoleh $\mathrm{r}=0,893$ dengan probabilitas $=0,000<0,05$, makaHo ditolak, yang berarti bahwa ada hubungan/korelasi yang signifikan antaravariabel Pendapatan Asli Daerah dengan Belanja Daerah. Variabel Dana Perimbangan dengannilai ujian $\mathrm{r}=0,998$, menggambarkan semakin tinggi Dana Perimbangan, maka akan semakin besar pulabelanja daerahnya.

\section{Uji Hipotesis}

Uji T (Parsial)

Tabel 7

Hasil Run SPSS untuk Coefficient Variabel a

\begin{tabular}{|c|c|c|c|c|c|}
\hline \multirow[b]{2}{*}{ Model } & \multicolumn{2}{|c|}{$\begin{array}{c}\text { Unstandardized } \\
\text { Coefficients }\end{array}$} & \multirow{2}{*}{\begin{tabular}{|c|}
$\begin{array}{c}\text { Standardized } \\
\text { Coefficients }\end{array}$ \\
Beta \\
\end{tabular}} & \multirow[b]{2}{*}{ t } & \multirow[b]{2}{*}{ Sig. } \\
\hline & B & Std. Error & & & \\
\hline 1 (Constant) & -1.906 & 1.070 & & -1.782 & .083 \\
\hline Dana Perimbangan & 1.030 & .010 & .998 & 100.218 & .00 \\
\hline
\end{tabular}

Terlihat pada kolom Coefficients model 1 terdapat nilai sig 0,000. Nilai sig lebih kecil dari nilaiprobabilitas 0,05 , atau nilai $0,000<0,05$, maka $\mathrm{H} 1$ diterima dan $\mathrm{Ho}$ ditolak. Variabel $\mathrm{X}$ mempunyaithitung yakni 100,218 dengan ttabel $=1,684$. Jadi thitung>ttabel dapat disimpulkan bahwa variabel Dana Perimbanganmemiliki kontribusi terhadap Belanja Daerah. Nilai t positif menunjukkan bahwa Dana Perimbangan mempunyaihubungan yang searah dengan Belanja Daerah. Jadi dapat disimpulkan Dana Perimbangan memiliki pengaruh signifikan terhadap Belanja Daerah.

Tabel 8

\section{Hasil Run SPSS Untuk Coefficient Variabel B}

Excluded Variables ${ }^{\mathrm{b}}$

\begin{tabular}{|l|r|r|r|r|r|}
\hline & & & & & Collinearity \\
Model & & & $\begin{array}{c}\text { Partial } \\
\text { Statistics }\end{array}$ \\
\cline { 3 - 6 } & Beta In & t & Sig. & Correlation & Tolerance \\
\hline 1 Pendapatan Asli Daerah & .008 a & .372 & .712 & .061 & .202 \\
\hline
\end{tabular}
a. Predictors in the Model: (Constant), Dana Perimbangan
b. Dependent Variable: Belanja Daerah

Terlihat pada kolom Coefficients model 1 terdapat nilai sig 0,712. Nilai sig lebih besar dari nilaiprobabilitas 0,05, atau nilai $0,712>0,05$, maka $\mathrm{H} 1$ ditolak dan Ho diterima. Variabel $\mathrm{X}$ mempunyaithitung yakni 0,372 dengan tabel=1,684. Jadi thitung<ttabel dapat disimpulkan bahwa variabel Pendapatan Asli Daerah memiliki kontribusi terhadap Belanja Daerah yang rendah. Nilai t positif menunjukkan bahwa Pendapatan Asli Daerah mempunyai hubungan yang searah dengan Belanja Daerah. Jadi dapat disimpulkan Pendapatan Asli Daerah memiliki pengaruh signifikanterhadap Belanja Daerah.

Uji F (Simultan)

Tabel 9

Hasil Run SPSS untuk Anova ANOVA $^{b}$

\begin{tabular}{|l|r|r|r|c|c|}
\hline Model & Sum of Squares & Df & Mean Square & F & Sig. \\
\hline 1 Regression & 231318.737 & 2 & 115659.369 & $4.908 \mathrm{E} 3$ & $.000^{\mathrm{a}}$ \\
Residual & 871.904 & 37 & 23.565 & & \\
Total & 232190.642 & 39 & & & \\
\hline
\end{tabular}

a. Predictors: (Constant), Dana Perimbangan, PAD

b. Dependent Variable: Belanja Daerah 
Dari tabel diperoleh nilai $\mathrm{F}_{\text {hitung }}$ sebesar 4,908 dengan nilai probabilitas $(\mathrm{sig})=0,000$. Nilai $F_{\text {hitung }}(4,908)<F_{\text {tabel }}$ $(2,54)$, dan nilai sig. lebih kecil dari nilai probabilitas 0,05 atau nilai $0,000<0,05$; maka $\mathrm{H}_{0}$ diterima, berarti secara bersama-sama (simultan) Pendapatan Asli Daerah dan Dana Perimbangan berpengaruh signifikan terhadap Belanja Daerah. $\mathrm{H}_{1}$ ditolak.

\section{Pembahasan}

Analisa Regresi Linier Berganda Untuk Pengaruh Pendapatan Asli Daerah dan Dana Perimbangan Terhadap Belanja daerah Pengujian atas pengaruh dana perimbangan dan PAD terhadap belanja daerah dimaksudkan untuk mengetahui apakah secara bersama-sama kedua variable tersebut berpengaruh signifikan terhadap belanja daerah dan variable mana yang lebih dominan. Berdasarkan hasil dari beberapa studi empiris sebelumnya (Zampelli 1986), Shah (2005), Slack (1979), Anderson (2005), Deller et al (2005), dan Abdulah dan halim (2006)) transfer atau grant dan pendapatan secara terpisah berpengaruh terhadap belanja daerah. Studi ini meregresi kedua variable pendapatan tersebut secara serentak sehingga dapat dibandingkan signifikan pengaruh keduanya terhadap belanja daerah (Abdulah dan Halim (2006)). Hasil analisis dapat dilihat pada Tabel 10 sebagai berikut:

$$
\text { Tabel } 10
$$

Hasil Regresi Berganda PAD dan DP Terhadap BD ANOVA $^{b}$

\begin{tabular}{|l|r|r|r|c|c|}
\hline Model & Sum of Squares & Df & Mean Square & F & Sig. \\
\hline 1 Regression & 231318.737 & 2 & 115659.369 & $4.908 \mathrm{E} 3$ & $.000^{\mathrm{a}}$ \\
Residual & 871.904 & 37 & 23.565 & & \\
Total & 232190.642 & 39 & & & \\
\hline
\end{tabular}

a. Predictors: (Constant), Dana Perimbangan, PAD b. Dependent Variable: Belanja Daerah

Berdasarkan Tabel 10 di atas hasil analisis dari regresiberganda Pendapatan dan asli daerah dan Dana Perimbangan terhadap Pengeluaran/Belanja daerah, adalah sebagai berikut:

1. Pengujian Hipotesis (Hipotesis 3-H3)

$\mathrm{H}_{0}: \mathrm{b}=\mathrm{b}=\ldots=0$ (ada pengaruhnya yang tidak signifikan dari variable PAD dan DP terhadap Belanja Daerah)

$\mathrm{H}_{1}$ : b \# b \# 0 (ada pengaruh yang signifikan dari variable PAD dan DP terhadap Belanja Daerah).

Dari uji anova atau $\mathrm{F}$ test, didapat $\mathrm{F}$ hitung adalah 4,908 dengan tingkat signifikan $=0,00$ jauh lebih kecil dari derajat kepercayaan 95\% $(\mathrm{a}=5 \%)$ maka model regresi bisa dipakai untuk memprediksi belanja daerah. Atau dengan kata lain PAD dan dana Perimbangan secara bersama-sama berpengaruh terhadap belanja daerah. Dan nilai t-statistik untuk model regresi sederhana dengan variable independen tunggal, nilai t-statistik untuk kedua variable mengalami kenaikan dibandingkan dengan regresi berganda (pendapatan asli daerah dan dana perimbangan terhadap belanja daerah). Ketika pendapatan asli daerah dan dana perimbangan diregresi secara serentak dengan pengeluaran/belanja daerah, maka nilai t-statistik keduanya masing-masing adalah 0,372 dan 44,187 (sehingga pendapatan asli daerah lebih kecil dari pada dana perimbangan). Sementara ketika kedua variable tersebut masing-masing diregresi secara sederhana terhadap pengeluaran atau belanja daerah, nilai t-statistik untuk dana pendapatan asli daerah adalah 0,191 (sehingga PAD lebih kecil dari pada dana perimbangan). Dengan demikian dapat dinyatakan bahwa signifikasi pengaruh pendapatan asli daerah (PAD) terhadap pengeluaran/belanja daerah (BD) lebih lemah daripada pengaruh dana perimbangan (DP) terhadap pengeluaran atau Belanja daerah (BD). Hasil ini berbeda dengan hasil 
yang diperoleh pada penelitian terdahulu oleh Ariefrahman (2006).

\section{KESIMPULAN}

Berdasarkan dari data-data hasil penelitian dapat disimpulkan bahwa:

1. Secara parsial Pendapatan Asli Daerah (PAD) dan Dana Perimbangan berpengaruh secara signifikan terhadap Belanja Daerah pada Kabupaten Tanah Laut.

2. Secara simultan Pendapatan Asli Daerah (PAD) dan Dana Perimbangan berpengaruh secara signifikan terhadap Belanja Daerah pada Kab. Tanah Laut.

3. Meningkatnya Belanja Daerah Kabupaten Tanah Laut dipengaruhi oleh Pendapatan Asli Daerah yang bersumber pada pendapatan pajak, retribusi, dan Badan Usaha Milik Daerah, dan yang berpengaruh Dominan adalah Dana Perimbangan yang berasal dari Dana Bagi Hasil, Dana Alokasi Umum, dan Dana Alokasi Khusus.

\section{DAFTAR PUSTAKA}

Abdullah, Syukry dan abdul Halim 2006. Pengaruh DAU dan PAD terhadap Belanja Pemerintah Daerah: studi kasus Kabupaten / Kota di Jawa dan Bali, Simposium Nasional Akuntansi IV, Surabaya.

Ahmad, J. 2001. Hubungan keuangan antara Pemerintah Pusat-daerah di Indonesia: Study Kasus Propinsi D.I Aceh, DKI Jakarta, dan Jawa timur. Yogyakarta: Disertai UGM

Badan Arsip daerah. 2007. Laporan Pertanggungjawaban Pelaksanaan APBD Tahun Anggaran 20022006

$2004 . \quad$ Laporan

Pertanggungjawaban Pelaksanaan APBD Tahun Anggaran 20072003
2009.

Laporan

Pertanggungjawaban Pelaksanaan APBD Tahun Anggaran 20072003

Badan Penerbit Universitas Jember. 2009 Pedoman penulisan karya ilmiah. Edisi Ketiga. Jember : Badan Penerbit Universitas Jember.

Bappeda dan BPS Kabupaten Tanah Bumbu. 2007. Kabupaten Tanah Laut dalam Angka , 2009. Kabupaten Tanah Laut dalam Angka , 2010. Kabupaten Tanah Laut dalam Angka

, 2012. Kabupaten Tanah Laut dalam Angka

Bappedakab. 2010. Indikator Pertumbuhan Ekonomi kabupaten Tanah Laut

Bastian, Indra. 2004. Manual Akuntansi Keuangan Pemerintah Daerah 2004. Yogyakarta: PPA FE UGM.

Da Costa, Matheus A.B. 2005. Tingkat Kemandirian Kota Tanah Laut ditinjau dari Aspek Keuangan Dalam Melaksanakan Otonomi Daerah. Yogyakarta: Tesis Pascasarjana. UGM.

Daves, N. 2009. Keuangan Pemerintah Daerah di Indonesia. Jakarta Edisi terjemahan. UI Press

Departemen Dalam Negeri dan Otonomi Daerah. 2003. Himpunan Peraturan Pemerintah Tahun 2003. Jakarta: Depdagri,

Departemen dalam Negeri. 2006. UndangUndang RI Nomor 17 Tahun 2006 tentang Keuangan daerah. Yogyakarta: UPP AMP YKPN.

Departemen dalam Negeri. 2007. UndangUndang, RI Nomor 2 Tahun 2007 tentang Perbendaharaan Negara. Yogyakarta: UPP AMP YKPN. , 2007.Undang-Undang Nomor 25 Tahun 2007 tentang Perencanaan Nasional. Yogyakarta: UPP AMP YKPN. 2007.Undang-Undang Nomor 32 Tahun 2007 tentang Pemerintah 
Daerah. Jakarta: Departemen komunikasi dan Informatika. , 2007.Undang-Undang Nomor 33 Tahun 2007 tentang Perimbangan Keuangan Daerah antara Pemerintah Pusat dan Pemerintah daerah. Jakarta: Departemen Dalam Negeri.

Halim, Abdul. 2004. Bunga Rampe Manajemen Keuangan Daerah. Yogyakarta: UPP YKPN.

Harianto, David. 2010. Hubungan antara Dana Alokasi Umum, Belanja Modal PAD dan Pendapatan perkapita. Makasar: Simposium Nasional Akuntansi X UNHAS Makasar.

Hasmizon.2005. Analisis Keuangan daerah dalam Mendukung Otonomi di Kabupaten Sawahlunto/sijunjung.

Yogyakarta: tesisPascasarjana UGM.

Hidayat, AriefRaiman. 2008. Pengaruh

Keuangan daerah dalam era otonomi Daerah studi kasus Kabupaten dan kota se- Jawa Timur. Surabaya: Skripsi airlangga.

Husaini. 2009. Pengantar Statistika. Edisi

Kedua, Jakarta: Sinar Grafika Offset.

Insukindro, Mardiasmo, Widayat W. Jaya, W.K. Purwanto, B.M, Halim, A, Suprianto, J. Purnomo. 2005. Peranan dan Pengelolaan Keuangan Daerah Dalam Usaha Peningkatan PAD. Yogyakarta: Buku 1, KKD FE UGM

Koswara, E. 2003. Menyongsong otonomi

Daerah Berdasarkan UndangUndang Nomor 22 Tahun 2010 : Suatu Telaahan dan Menyangkut Kebijakan, Pelaksanaan

Kompleksitas. Jakarta: CSIS XXIX Nomor 1.

Mudrajat. 2008. Otonomi daerah dalam Transisi, Makalah, Temu Alumni dan Seminar Nasional Manajemen Keuangan Daerah dalam Era
Globalisasi. Yogyakarta: KKDFE, UGM.

Landiyanto. 2008. Kinerja Keuangan dan Strategi Pembangunan kota di Era Otonomi daerah: Studi Kasus Kota Surabaya. Surabaya: UNAIR.

Langoday, Thomas Ola. 2009. Pengaruh Desentralisasi dan Pemerintah Fiskal terhadap Kapasitas dan Kebutuhan Fiscal serta Pajak Daerah di Propinsi Nusa Tenggara Timur. Surabaya: Disertai Airlangga.

Mardiasmo. 2005. Otonomi dan Manajemen Keuangan Daerah. Yogyakarta: Andi Yogyakarta.

Nanga, Muana. 2008. Otonomi Keuangan Daerah Tingkat II: Suatu Studi Kasus Di Kabupaten Malang, Probolinggo dan trenggalek propinsi Jawa Timur, Yogyakarta: Tesis Pascasarjana, PPS-UGM.

Nasir, Moh. 2009. Metode Penelitian. Jakarta: Ghalia Indonesia,

Republik Indonesia. 2009. Peraturan Menteri Dalam Negeri Nomor 13 Tahun 2009 tentang Pedoman Pengelolaan Keuangan Daerah.

Tambunan, T. H Tulus. 2004. Perekonomian Indonesia. Jakarta: Ghalia Indonesia.

Sidik, Macfud, Natzir P, Rudy. H. 2004. Perimbangan Keuangan Pusat dan Daerah sebagai Pelaksanaan desentralisasi Fiskal (Antara teori dan aplikasinya di Indonesia). Jakarta: Makalah Pada seminar implementasi kebijakan Otonomi daerah di Indonesia.

Singaribuan, effendi. 1995. Metode Penelitian Survei. Jakarta: Pustaka LP3S

Sondakh.2003. Ketimpangan Ekonomi dalam Era Otonomi Daerah. Jakarta: Makalah pada Seminar tentang Krisis moneter dalam era Otonomi Daerah 